\title{
Decision Support System for Foundation Beneficiaries Using theSimple Additive Weighting (SAW) Method
}

\author{
Elfrida Tamba \\ Stmik Budi Darma, Indonesia \\ Email : elfridatamba@gmail.com
}

Received : 19 October 2020

Revised : 29 November 2020

Accepted : 01 December 2020

C 2020 The Author: Published by. Cattleya Darmaya Fortuna

\begin{abstract}
Receipt of compensation funds for underprivileged students needs to be selected so that they are notwrong in providing assistance, so that the recipients of assistance are students who deserve to receive. The decision support system is an effective way of selecting students who need compensation funds. The criteria are as a stage for selecting students who are entitled to grant aid, with these criteria all students who participate in receiving the compensation funds will be ranked. The results of the ranking are based on calculations, the first order is Farhan Rifai with a value of0.8; second place is Sidratul Muntaha with a value of 0.7666
\end{abstract}

Keywords: Decision Support System, Compensation, SAW Method.

\section{INTRODUCTION}

The Compensation Template is a form of our concern for fellow creatures of God which should be carried out sincerely and voluntarily. Compensation is a fund allocated and issued by an agency/foundation to underprivileged people such as orphans. Giving compensation by the foundation to underprivileged students is an activity that has become a good habit to be carried out every year with the aim of easing the burden for those in need. The MDTANurul Ikhwan Foundation is one of the foundations that has made the activity of providing compensation to underprivileged students in the family economy and orphans a habit every year with a predetermined allocation of funds. The foundation in providing compensation to students every year is carried out with a direct system for paying monthly tuition fees and data collection is still carried out in recording in the ledger so that it is less effective and efficient in its implementation. Data collection that has not used a computerized systemor manual data collection creates difficulties, such as in selecting students who receive compensation alternately each year with the allocation of compensation funds which will be given to $10 \%$ of the total number of students in each class per year with the allocated funds. The problem of decision making is basically a form of selection from various alternative actions that may be chosen, the process through a certain mechanism in the hopeof producing the best decision.[1]. The SAW method is a method used in dealing with Fuzzy Multiple Attribute Decision Making (FMADM) situations or decision making by finding the optimal alternative from a number of alternatives with certain criteria.[2]. The Simple Additive Weighting (SAW) method is known as the weighted addition method. Basically the working concept of SAW is to find the weighted sum of the performance of each alternative on all attributes. The total score for the alternatives is obtained by adding 
up all the multiplication results between the rating (which can be compared acrossattributes) and the weight of each attribute[3]. The rating of each attribute must be dimension-free in the sense that it has passed the previous matrix normalization process. Previous research has journals that use the Simple Additive Weighting (SAW) method.[4]. Designing a system that can assist the foundation in determining which students are eligibleto receive foundation compensation for the annual period, so that it can be more efficient and effective in its implementation[5]. With the Simple Additive Weighting (SAW) method, the results of the calculation of ranking (rank) and the amount of the recommended aid fund are different[6]. The provision of financial assistance or financing is very helpfulfor small entrepreneurs in the context of business expansion, it's just that for the bank this also causes problems, because of the large number of problematic refunds.[7]. The SAW method because it provides the highest alternative value and gives the best ranking results[8]. The SAW method is carried out by finding the weight value for each criterion, and then making a process that will determine the optimal ranking of the alternative, whichis the best student who will be considered by decision makers to get a scholarship.[9]. The method used in this study uses the SAW method, namely the Decision Making System method[10].

\section{METHODS}

\section{Decision Support System}

Basically DSS is almost the same as SIM because it uses a database as a data source[11]. DSS originates from MIS because it emphasizes the function of supporting decision makers at all stages, although the actual decision remains the exclusive authority of the decision maker. A class of computerized information systems at a higher level is the Decission Support System (DSS).[12]. DSS is almost the same as traditional MIS in that they both depend on a database as a data source. Although the actual decision is still the exclusive authority of the decision maker.

\section{Simple Additive Weighting}

The Simple Additive Weighting (SAW) method is often also known as the weightedaddition method[13]. The basic concept of the Simple Additive Weighting (SAW) method is to find the weighted sum of the performance ratings on each alternative on all attributes[14].

$$
\mathbf{r}_{i j}=\left\{\begin{array}{l}
\frac{\boldsymbol{x}_{i j} \text { If } \mathrm{j} \text { is an attribute of benefit (Benefit) }}{\max \boldsymbol{X}_{i j} i} \\
\frac{\boldsymbol{m i n} \boldsymbol{X}_{i j} i}{\boldsymbol{X}_{i j}} \quad \text { If } \mathrm{j} \text { is the cost attribute (Cost) }
\end{array}\right.
$$

Where rij is the normalized performance rating of alternative $\mathrm{Ai}$ on attribute $\mathrm{Cj} ; \mathrm{i}=1,2, \ldots, \mathrm{m}$ and $\mathrm{j}=1,2, \ldots, \mathrm{n}$. The preference value for each alternative ( $\mathrm{Vi}$ ) is given:

$$
\begin{aligned}
r i j & =\text { Normalized work rating. } \\
\text { maxi } & =\text { maximum value of each row and column. mini } \\
& =\text { the maximum value of each row and column.Xij } \\
& =\text { rows and columns of the matrix. }
\end{aligned}
$$


(rij)is the normalized performance rating of the alternative (Ai) on the attributes $(\mathrm{Cj}) \mathrm{i}=$ $1,2 \ldots, m$ and $j=1,2 \ldots, n$.

$V_{i}=\sum_{j=1}^{h} W_{j} r_{i j}$

A larger Vi value indicates that alternative Ai is preferred.

Where :

$V i \quad=$ final value of the alternative.

$W i \quad=$ predetermined weight.

rij $\quad=$ matrix normalization

a larger value indicates that the alternative is preferred.

There are several steps in completing the Simple Additive Weighting (SAW) method. Which is applied as follows:

1. Determine the criteria used as a reference in decision support, namely $\mathrm{Ci}$.

2. Determine the suitability rating of each alternative on each criterion.

3. Make a decision matrix based on the criteria (Ci).

4. Then normalize the matrix based on the equation that is adjusted to the type of attribute (profit attribute or cost attribute) in order to obtain a normalized matrix R.

5. The final result is obtained from the ranking process, namely the addition of the normalized matrix multiplication $\mathrm{R}$ with the weight vector so that the largest value is chosen as the best alternative (Ai) as the solution.

\section{Annual Period Foundation Compensation}

Compensation is a form of our concern for fellow creatures of God which should be carried out sincerely and voluntarily[15]. Compensation is a fund allocated and issued by an agency/foundation to underprivileged people such as orphans. Foundation compensation for the annual period is a fund in the form of assistance allocated and issued by a foundation to underprivileged students and the provision of compensation is carried out on anannual/periodic period every year.[16]. Compensation provided by the foundation to students with various criteria/alternatives that will be a reference in providing compensation. The criteria/alternatives for receiving foundation compensation include:

1. Students who are less well off in the family economy (amount of parents' income).

2. Students with family status, namely: orphans, orphans and orphans.

3. Students with how many children their parents depend on.

4. Students who excel / win from grade 2 to grade 6.

\section{RESULTS \& DISCUSSION}

\section{Application of the SAW Method}

In determining students who are entitled to receive compensation at the MDTA Nurul Ikhwan Foundation, the school/foundation selects students-student and those who are entitled to become students who receive foundation compensation for the annual period with predetermined criteria. One of the solutions to the FMADM problem, criteria and weights are needed in carrying out the calculations so that the best alternative will be obtainedare as follows : 
Determining each of the criteria can be seen in the table below:

Table 1: Code and Criteria Terms

\begin{tabular}{lll}
\hline Code & Criteria & Attribute \\
\hline C1 & Parents' Income & Benefits \\
C2 & Family Status & Benefits \\
C3 & Parental Dependence & Cost \\
C4 & Student Achievement & Benefits \\
\hline
\end{tabular}

Furthermore, decision makers give preference weights to each criterion as $\mathrm{W}$ as shown in table 2:

Table 2 : Determination of W . Value

\begin{tabular}{ccc}
\hline Criteria & Range (\%) & Weight \\
\hline C1 & 40 & 0.40 \\
C2 & 25 & 0.25 \\
C3 & 20 & 0.20 \\
C4 & 15 & 0.15 \\
\hline
\end{tabular}

Criteria for the amount of parental income.

Table 3 : Parental Income Criteria

\begin{tabular}{|c|c|c|}
\hline Parent's income $(\mathrm{C} 1)$ & Variable & Score \\
\hline $\mathrm{C} 1<=$ IDR 500,000 & Very high & 1 \\
\hline $\begin{array}{l}\mathrm{C} 1>\text { IDR } 500 \text { thousand }<\mathrm{C} 1<=\mathrm{IDR} 1 \\
\text { million }\end{array}$ & Tall & 0.75 \\
\hline $\begin{array}{l}\mathrm{C} 1>\mathrm{IDR} 1 \text { million }<\mathrm{C} 1<=\text { IDR } 1.5 \\
\text { million }\end{array}$ & Currently & 0.50 \\
\hline $\begin{array}{l}\mathrm{C} 1>\text { IDR } 1.5 \text { million }<\mathrm{C} 1<=\text { IDR } \\
2.5 \text { million }\end{array}$ & Low & 0.25 \\
\hline C1> IDR 2.5 million & Very low & 0 \\
\hline
\end{tabular}

Status criteria in the family

Table 4 : Criteria for Family Status

\begin{tabular}{lcl}
\hline Family Status $(\mathrm{C} 2)$ & Variable & Score \\
\hline Orphans & Very high & 1 \\
Orphans & Tall & 0.75 \\
Orphans & Currently & 0.50 \\
\hline
\end{tabular}


Table 5 : Student Data Submitted

\begin{tabular}{cllll}
\hline \multirow{2}{*}{ Alternative } & & \multicolumn{2}{c}{ Criteria } \\
& Parents' Income & Family Status & $\begin{array}{l}\text { Parental } \\
\text { Dependence }\end{array}$ & $\begin{array}{l}\text { Student } \\
\text { achievement }\end{array}$ \\
\hline 1 & IDR 500,000 & orphan & 3 children & 2 \\
2 & IDR 800,000 & orphan & 2 children & 4 \\
3 & IDR 1,000,000 & Orphan & 4 kids & 1 \\
4 & IDR 1,400,000 & orphan & 3 children & 3 \\
5 & IDR 2,500,000 & orphan & 4 kids & 2 \\
\hline
\end{tabular}

The sample above is data from students who become alternatives, namely, A1 (Farhan Rifai), A2 (Syashi Ajeng Sachira), and A3 (Sidratul Muntaha), A4 (Aqila Zahra Daulay), and A5 (Alif Putra Kelana).

The ranking calculation value for each alternative with a value of Vi can be seen in the following table:

Table 6: Ranking Calculation Results

\begin{tabular}{lll}
\hline Alternative & Vi & Rank \\
\hline A1 & 0.8 & 1 \\
A2 & 0,6625 & 3 \\
A3 & 0.7666 & 2 \\
A4 & 0.5 & 4 \\
A5 & 0,4666 & 5 \\
\hline
\end{tabular}

From the calculation above, the first order is Farhan Rifai with a value of 0.8 ; second place is Sidratul Muntaha with a value of0.7666; Syashi Ajeng Sachira with grades0.6625; fourthplace is Aqila Zahra Daulay with a value of 0.5 and the last order is Alif Putra Kelana with a value of 0.4666 .

\section{CONCLUSION}

Based on the results of research and discussion of the decision support system for recipients of foundation compensation for this annual period, conclusions can be made, including: With this research, it can find out the requirements or criteria needed in applying for foundation compensation recipients such as criteria seen from the amount of parental income students, student status in the family, number of dependents of parents, and student achievements or champions. Applying the SAW (Simple Additive Weighting) method produces values from determining criteria, weighting, compatibility ratings, normalization, and rankings so as to produce values for each criterion. Designing a decision support system for the calculation above, the first order is Farhan Rifai with a value of0.8; second place is Sidratul Muntaha with a value of0.7666; Syashi Ajeng Sachira with grades0.6625;

\section{REFERENCES}

[1.] ED Sri Mulyani, "Comparative Analysis of Decision Support Systems Using the

[2.] SAW Method With WP In Loans," CogITo Smart J., vol. 5, no. 2, 2019, doi:10.31154/cogito.v5i2.151239-251. 
[3.] H. Abijono, "Comparative Analysis of Simple Additive Weighting and Fuzzy Algorithms in Decision Support Systems," LIGHTtech, vol. 7, no. 1, 2019, doi:10.47047/ct.v7i1.5.

[4.] Fitriani, Ilyas, and Bayu Rianto, "DECISION SUPPORT SYSTEM OF GRANTING ASSISTANCE TO FISHERMEN GROWS BY THE MARINE AND FISHERIES DEPARTMENT," J. SOFTWARE, vol. 1, no. 1, 2019,doi:10.32520/jupel.v1i1.778.

[5.] B. Suprapty, LD Utami, and ABW Putra, "SELECTION OF PROSPECTIVE SCHOLARSHIP RECIPIENTS PT. ADIMITRA BARATAMA NUSANTARA USING SIMPLE ADDITIVE WEIGHTING METHOD,"POSITIVE J. Sist. and Technol. inf., vol. 5, no. 2, 2019, doi:10.31961/positive.v5i2.791.

[6.] GYKSS Pahu, "DECISION SUPPORT SYSTEM FOR SELECTING RECIPIENTS OF POOR STUDENT AID USING THE SIMPLE ADDITIVE WEIGHTING (SAW) METHOD," Expert J. Manaj. Sis. inf. and Technol., vol. 8, no. 2, 2018, doi:10.36448/jmsit.v8i2.1116.

[7.] WY Arkadia and EH Parmadi, "Decision Support System for Determining Mck Development Funds Using Fuzzy Simple Additive Weighting," CogITo Smart J., vol. 3, no. 2, 2018, doi:10.31154/cogito.v3i2.76.263-274.

[8.] AO Riyandi, N. Dengen, and Islamiyah, "Decision Support System for the Eligibility of Providing Funds or Credit Assistance for Small and Medium Enterprises (SMEs) at Bank Negara Indonesia (BNI)," Pros. SAKTI (Seminar on Computing and Information Technology), vol. 2, no. 1, 2017.

[9.] MY B2042141012, "INFLUENCE OF QUALITY PERCEPTIONS, ATTITUDE TO TV ADVERTISING AND BRAND IMAGE TOWARDS REPURCHASING INTENTION (Study on Consumers of Indomie Brand Instant Noodles in Pontianak City)," Equator J. Manag. Entrep., vol. 8, no. 1, 2019, doi:10.26418/ejme.v8i1.35743.

[10.] D. Pertiwi and K. Kusmanto, "Scholarship Admission System at Al-Washliyah University Labuhanbatu Using the SAW (Simple Additive Weighting) Method," U- NET J. Tek. information., vol. 3, no. 1, 2019, doi:10.52332/u-net.v3i1.177.

[11.] DS Purnia, L. Lena, and R. Ratningsih, "Information System for Determining PKH Candidates Using the SAW Method (Case Study of PPKH Kab.Tasikmalaya)," Indonesia. J. Softw. eng., vol. 5, no. 2, 2019, doi:10.31294/ijse.v5i2.7154.

[12.] AA Azhari, Y. Nyura, and A. Najib, "Comparison of the SAW and TOPSIS Methods on the Admission of Field Work Practice Students," Semin. Nas. Computer Science. and Technol. inf. 2018, vol. 3, no. 1, 2018.

[13.] D. Puspitasari, "DESIGN AND DEVELOPMENT OF WEB-BASED EMPLOYEESAVELOAN COOPERATIVE INFORMATION SYSTEM," J. Pillar Nusa Mandiri, vol. XI, no. 2, 2016.

[14.] SN Rochmawati and F. Marisa, "Web-Based Home Recommendation SystemUsing SAW Method at PT.Inproperty," JOINTECS (Journal Inf. Technol. Comput. Sci., vol. 3, no. 2, 2018, doi:10.31328/jointecs.v3i2.808.

[15.] R. Fauzan, Y. Indrasary, and N. Muthia, "Decision Support System for Bidik Misi Scholarship Admission at POLIBAN with Web-Based SAW Method," J. Online Information., vol. 2, no. 2, 2018, doi:10.15575/join.v2i2.101.

[16.] R. Setiawati, "ZIS (ZAKAT, INFAK, SEDAKAH) MANAGEMENT IN THE DEVELOPMENT AND DEVELOPMENT OF THE POTENTIAL OF ORPHANS AT THE MANDIRI ORIGINAL FOUNDATION, LAMPUNG," COMMUNICATION, vol. 1, no. 2, 2019, doi:10.24042/komunika.v1i2.4747.

[17.] Iswatul Hasanah, EMPOWERMENT OF ORPHANS THROUGH THE GOAT COMPENSATION PROGRAM BY THE AL FALAH SIDOARJO SOCIAL FUND FOUNDATION, vol. 11, no. 1.2019. 